\title{
Evaluation of aflibercept and ziv-aflibercept binding affinity to vascular endothelial growth factor, stability and sterility after compounding
}

\author{
Julia de Lima Farah ${ }^{1 *}$, Ronaldo Sano ${ }^{1}$, leda Maria Longo Maugéri ${ }^{2}$, Daniela Teixeira², Mayari Eika Ishimura², \\ Gabriela Martins ${ }^{2}$, Lycia M. J. Mimica ${ }^{3}$, Cely Barreto da Silva ${ }^{3}$, Carsten H. Meyer ${ }^{4}$, João Rafael de Oliveira Dias ${ }^{4}$, \\ Gabriel Costa de Andrade ${ }^{4}$ and Michel Eid Farah ${ }^{4}$
}

\begin{abstract}
Purpose: To investigate the binding affinity, stability, and sterility of aflibercept and ziv-aflibercept to vascular endothelial growth factor (Holash et al. in Proc Natl Acad Sci USA 99(17):11393-11398, 2002. https://doi.org/10.1073/ pnas.172398299) after compounding and storage for up to 28 days at $4{ }^{\circ} \mathrm{C}$ and $-8{ }^{\circ} \mathrm{C}$.

Methods: Tuberculin-type 1-mL syringes were prepared containing aflibercept ( $40 \mathrm{mg} / \mathrm{mL}$ ) and ziv-aflibercept ( $25 \mathrm{mg} / \mathrm{mL}$ ). Samples were stored at $4{ }^{\circ} \mathrm{C}$ and $-8{ }^{\circ} \mathrm{C}$ for 0,14 , and 28 days and evaluated for the binding affinity of anti-VEGF to VEGF and stability using enzyme-linked immunosorbent assays. The evaluation of sample sterility was performed.
\end{abstract}

Results: Laboratory trials with aflibercept and ziv-aflibercept showed preservation of the drug-binding capability to recombinant VEGF when stored in plastic syringes for up to 28 days at $4{ }^{\circ} \mathrm{C}$ and $-8^{\circ} \mathrm{C}$. No significant decrease in mass or concentration were observed. Microbiologic evaluations did not detect contamination in the syringes.

Conclusions: The current study corroborates that compounded anti-VEGF drugs aflibercept and ziv-aflibercept do not loose stability or binding affinity and do not become contaminated if prepared under sterile conditions and stored at $4^{\circ} \mathrm{C}$ or $-8^{\circ} \mathrm{C}$ for 14 or 28 days.

Keywords: Retina, Anti-VEGF, Aflibercept, Ziv-aflibercept, Compounding

\section{Background}

Anti-vascular endothelial growth factor (VEGF) therapy became available and revolutionized the treatment of retinal disorders related to angiogenesis [2]. These drugs reduce vascular permeability and growth and leakage of new vessels involved in choroidal and retinal neovascularization $[14,16]$.

Anti-VEGF drugs used in Ophthalmology include an aptamer (pegaptanib, Macugen, Bausch \& Lomb,

\footnotetext{
*Correspondence: julialfarah@gmail.com

1 Department of Ophthalmology, Santa Casa de Misericórdia of São Paulo,

Rua Dr. Cesario Mota Junior 112, São Paulo, SP 01221-020, Brazil

Full list of author information is available at the end of the article
}

Rochester, NY), a humanized monoclonal antibody (bevacizumab, Avastin, Genentech, Inc., South San Francisco, CA), an antibody fragment (ranibizumab, Lucentis, Genentech Inc.), and fusion proteins (aflibercept, Eylea, Regeneron Pharmaceuticals, Tarrytown, NY, and Bayer, Leverkusen, Germany), conbercept (Kanghong Biotech, Chengdu, China), and ziv-aflibercept (Zaltrap, Sanofi-Aventis, Bridgewater, NJ, and Regeneron Pharmaceuticals).

Aflibercept is a recombinant fusion protein engineered by the fusion of two extracellular domains of VEGF receptors 1 and 2 of human VEGF to the Fc portion of human immunoglobulin G1. In contrast to other monoclonal antibodies, aflibercept binds to VEGF-A, 
VEGF-B, and placental growth factor (PIGF). Aflibercept binds to VEGF-A with a tenfold higher affinity than other commercially available monoclonal antibodies. The highest VEGF-A binding affinity and the VEGF-B and PlGF binding capacity make this drug potentially more beneficial compared to bevacizumab and ranibizumab [21, 23].

The molecule of ziv-aflibercept is identical to that of aflibercept but at a lower concentration (ziv-aflibercept, $25 \mathrm{mg} / \mathrm{mL}$; aflibercept, $40 \mathrm{mg} / \mathrm{mL}$ ) and different osmolarities (ziv-aflibercept, $1000 \mathrm{mOsm} / \mathrm{kg}$; aflibercept, $300 \mathrm{mOsm} / \mathrm{kg}$ ) [24]. Aflibercept is isosmolar compared to the human vitreous and undergoes a different purification process, while ziv-aflibercept is hyperosmolar compared to the human vitreous $[8,29]$. In 2012, the US Food and Drug Administration approved intravenously administered ziv-aflibercept for treating colorectal carcinoma refractory to or progressive after an oxaliplatin regimen $[8,29]$ and is not approved for intravitreal administration. However, studies from many countries have suggested that the drug might be a safe and effective alternative intravitreal treatment for retinal disorders [1, $3-5,9,11-13,24,25,34]$.

Anti-VEGF drugs are used worldwide with good clinical results and are commercially available in sterile vials. According to the manufacturers' instructions, the drugs should be stored between $2^{\circ}$ and $8^{\circ}$, and the medications should not be frozen. Each vial has a total volume higher than the recommended dose for intravitreal administration $(0.05-0.08 \mathrm{~mL})$. Besides, for aflibercept and ranibizumab, approved for intravitreal administration, a single-use vial is recommended, although some ophthalmologists use the same vial for from two to four patients. For bevacizumab and ziv-aflibercept, which are used offlabel for intravitreal administration, one vial can be used for up to 40 patients, excluding the residual volume in the vials, needles, or syringes.

Due to the clinical applicability of these drugs and high cost, the use of lower cost compounded single-use vials is important. Compounding is the subdivision of the packaging of a drug into individual parts to facilitate the availability of the amount established by the medical prescription [32] to reduce the treatment cost.

Precautions must be taken during compounding to perform this procedure in a sterile manner, maintain the sterility after compounding and storage, and maintain the biologic activity of the medication.

Ocular complications after intravitreal injections are well described, including infectious endophthalmitis. The reported incidence rates of infectious endophthalmitis after intravitreal anti-VEGF range from 0.02 to $0.08 \%$. Studies have shown that the compounding of antiVEGF drugs, assuming that regulatory surveillance was followed strictly, is unrelated to increases in ocular infectious complications [20].

The maintenance of the biologic activity of the medication can be assessed using specific assays such as enzymelinked immunosorbent assay (ELISA) to determine the VEGF binding affinity and recovery of aflibercept and ziv-aflibercept after storage in syringes. Therefore, it would be possible to analyze the stability and sterility after compounding and storage under different temperature conditions $\left(4{ }^{\circ} \mathrm{C}\right.$ and $\left.-8{ }^{\circ} \mathrm{C}\right)$ for up to 28 days.

\section{Methods}

This experimental study to evaluate the binding in vitro affinity of commercially available antibodies to VEGF, loss of structure, and sterility under different storage conditions was performed in the laboratory of the Discipline of Immunology of the Department of Microbiology, Immunology and Parasitology of the Federal University of São Paulo-Paulista Medical School (UNIFESP/EPM) and the laboratory of Microbiology of the Department of Microbiology in the Department of Pathology of the Medical Sciences Faculty of Santa Casa of São Paulo from January to May 2017.

\section{Samples}

Under sterile conditions, 1-mL tuberculin-type syringes were prepared with $0.05 \mathrm{~mL}$ of aflibercept $(40 \mathrm{mg} / \mathrm{mL})$ or $0.08 \mathrm{~mL}$ of ziv-aflibercept $(25 \mathrm{mg} / \mathrm{mL})$. Samples were stored at $4{ }^{\circ} \mathrm{C}$ to $-8{ }^{\circ} \mathrm{C}$ for 14 or 28 days. For each drug, three syringes were prepared for each medication as replicates of each condition. A syringe also was prepared for each medication before the assays and was referred as pre-assay. The preparation of the syringes and the experimental assays described below were carried out at the Immunology Division of Microbiology, Immunology and Parasitology Department of Federal University of São Paulo (UNIFESP/EPM).

\section{Anti-VEGF recovery of aflibercept and ziv-aflibercept after different storage conditions}

The ELISA designed to detect anti-VEGF antibodies, a human monoclonal IgG, of which aflibercept and zivaflibercept are constituted, was performed as described by Dib et al. [15]. This assay evaluated the recovery of anti-VEGF drugs after the drugs were stored in polypropylene syringes for 0,14 , or 28 days at $4{ }^{\circ} \mathrm{C}$ and $-8{ }^{\circ} \mathrm{C}$. Briefly, each sample obtained from the syringes was added to the ELISA 96-well plates (High Binding, Corning, NY) in replicates $(50 \mu \mathrm{L} /$ well $)$ of the samples diluted in $0.9 \%$ saline $(1: 256,000$, for aflibercept; $1: 128,000$, for ziv-aflibercept). The standard curves of aflibercept and ziv-aflibercept were performed by serial dilution in saline, starting at 1:64,000 dilution. These standard curves and 
the initial dilution of the medications had been standardized previously. The plates were incubated overnight at $37^{\circ} \mathrm{C}$. After washing with phosphate-buffered saline (PBS) with Tween 0.05\% (PBST, Tween 20, Synth Diadema, SP, Brazil), $150 \mu \mathrm{L} /$ well of blocking buffer solution (PBS-bovine serum albumin 1\% [BSA], Sigma, St. Louis, $\mathrm{MO}$ ) was added to eliminate the non-specific sites, and the plates were incubated for $1 \mathrm{~h}$ at room temperature. After washing, $50 \mu \mathrm{L}$ of horseradish peroxidase (HRP)conjugated anti-human IgG was added to each well at a dilution of 1:10,000 (KPL, SeraCare Life Sciences, MA, EUA) for $1 \mathrm{~h}$ at room temperature. Plates were washed and the enzymatic reaction was developed by the addition of $1 \mathrm{mg} / \mathrm{mL}$ of o-phenylenediamine (OPD, Sigma) diluted in phosphate-citrate buffer containing $0.03 \%$ of hydrogen peroxide $(100 \mu \mathrm{L} /$ well). The reaction was interrupted with the addition of $50 \mu \mathrm{L}$ of $4 \mathrm{~N}$ sulfuric acid (Dinamica Química Contemporânea LTDA, SP, Brazil) solution/well. The optical density (OD) was measured at $492 \mathrm{~nm}$ with an ELISA reader (EnSpire, Multimode Plate Reader, PerkinElmer do Brasil, SP, Brazil). AntiVEGF antibody was detected in each sample by concentration $(\mu \mathrm{g} / \mathrm{mL})$, based on the respective standard curve, calculated using GraphPad Prism version 5.0 software (GraphPad Software Inc., La Jolla, CA), and converted to recovered mass $(\mu \mathrm{g})$.

\section{Aflibercept and ziv-aflibercept VEGF binding affinity under different storage conditions}

The binding affinity evaluation of commercially available anti-VEGF antibodies (aflibercept and ziv-aflibercept) was performed using a standardized ELISA. (Nunes [26] unpublished) ELISA plates (High Binding) were coated with $1 \mu \mathrm{g} / \mathrm{mL}(50 \mu \mathrm{L} /$ well) of capture antibody specific to human VEGF (R\&D Systems Inc., Minneapolis, MN), in PBS and incubated overnight at room temperature. After washing with PBST, $150 \mu \mathrm{L} /$ well of PBS-BSA $1 \%$ was added to eliminate non-specific biding sites for $1 \mathrm{~h}$ at room temperature. After this period and washing, $50 \mu \mathrm{L} /$ well of human recombinant VEGF (R\&D Systems Inc.) was added at $15,000 \mathrm{pg} / \mathrm{mL}$ and followed by incubation for $2 \mathrm{~h}$ at room temperature. Meanwhile, during the last hour of incubation, the samples obtained from the syringes were maintained at $37{ }^{\circ} \mathrm{C}$. After washing, $50 \mu \mathrm{L} /$ well of the samples was diluted in saline and added in replicates at 1:200,000 dilution for aflibercept and 1:100,000 dilution for ziv-aflibercept. To determine a concentration curve, serial dilutions in saline of aflibercept and ziv-aflibercept in a ratio of 1:2 starting at 1:50,000 were performed. This concentration curve was standardized previously, thus defining the initial dilution of the drugs. This was followed by an additional incubation at $37{ }^{\circ} \mathrm{C}$ for $2 \mathrm{~h}$. After washing the plates, $50 \mu \mathrm{L}$ of
HRP-conjugated anti-human IgG (KPL) was added at the dilution of 1:5,000. After incubation at room temperature for $1 \mathrm{~h}$ and washing, the enzymatic reaction was performed as described previously to determine the OD at $492 \mathrm{~nm}$. The binding affinity of anti-VEGF to the recombinant human VEGF molecule was detected in each sample by concentration $(\mu \mathrm{g} / \mathrm{mL})$, based on the respective standard curve, calculated using GraphPad Prism version 5.0 software.

\section{Sample sterility}

For each syringe of aflibercept and ziv-aflibercept and storage conditions of $4{ }^{\circ} \mathrm{C}$ and $-8{ }^{\circ} \mathrm{C}, 12 \mu \mathrm{L}$ of the stored material was inoculated on sterile filter paper discs $6 \mathrm{~mm}$ in diameter. The discs, which were completely saturated with the drugs, were placed on blood agar plates for 5 days and stored at $35 \pm 2{ }^{\circ} \mathrm{C}$. This procedure was performed under aseptic conditions and an unsaturated disc was incubated under the same conditions as a control.

\section{Data analysis}

The statistical differences between samples were analyzed by one-way analysis of variance followed by Bonferroni's multiple comparisons test using GraphPad Prism version 5.0 software.

\section{Results}

Polypropylene syringes were prepared with aflibercept and ziv-aflibercept. To evaluate the amount of recovered anti-VEGF antibody after storage for different times and at different temperatures, an ELISA assay was performed to determine the mass of the anti-VEGF antibody present in the stored syringes and in the pre-assay syringe.

Table 1 shows that the pre-assay syringe of aflibercept showed no significant loss of anti-VEGF antibody (2.03 $\mathrm{mg})$ compared to the expected mass $(2.05 \mathrm{mg}$ ), according to the initial concentration and subsequent dilutions. There was also no difference in the anti-VEGF recovery when aflibercept was stored after compounding (Table 1). After storage for 14 days at $4{ }^{\circ} \mathrm{C}$ and $-8{ }^{\circ} \mathrm{C}$, the measured aflibercept masses were 2.08 and $2.21 \mathrm{mg}$, respectively; after 28 days, 2.09 and $1.97 \mathrm{mg}$ were detected, respectively, for $4{ }^{\circ} \mathrm{C}$ and $-8{ }^{\circ} \mathrm{C}$.

Similarly, there was no significant loss of mass for zivaflibercept in the pre-assay syringe prepared $(1.33 \mathrm{mg})$ compared to the anti-VEGF mass expected to be measured $(1.28 \mathrm{mg})$ (Table 1). Regardless of the storage conditions, there was no significant difference in the measured anti-VEGF antibody (Table 1) compared to the pre-assay condition stored at $4{ }^{\circ} \mathrm{C}$ or $-8{ }^{\circ} \mathrm{C}$, for $14(1.17$ and $1.26 \mathrm{mg}$, respectively) or 28 days (1.28 and $1.25 \mathrm{mg}$, respectively). 
Table 1 Anti-VEGF antibody recovered mass in aflibercept and ziv-aflibercept subjected to different storage conditions

\begin{tabular}{lll}
\hline & \multicolumn{2}{l}{ Anti-VEGF recovered mass $(\mathbf{m g})$} \\
\cline { 2 - 3 } & Aflibercept & Ziv-aflibercept \\
\hline Expected mass & 2.05 & 1.28 \\
Pre-assay & $2.03 \pm 0.02$ & $1.33 \pm 0.01$ \\
14 days $/ 4{ }^{\circ} \mathrm{C}$ & $2.08 \pm 0.10$ & $1.17 \pm 0.14$ \\
14 days $/-8^{\circ} \mathrm{C}$ & $2.21 \pm 0.02$ & $1.26 \pm 0.11$ \\
28 days $/ 4^{\circ} \mathrm{C}$ & $2.09 \pm 0.17$ & $1.28 \pm 0.00$ \\
28 days $/-8^{\circ} \mathrm{C}$ & $1.97 \pm 0.10$ & $1.25 \pm 0.06$
\end{tabular}

Different samples of aflibercept and ziv-aflibercept were added to ELISA plates and detected by HRP-conjugated anti-human IgG and $\mathrm{H}_{2} \mathrm{O}_{2}$-OPD substrate. Anti-VEGF quantification ( $\mathrm{mg}$ ) was based on a standard curve performed with both drugs. The drugs were initially diluted in saline (1:256,000 for aflibercept; $1: 128,000$ for ziv-aflibercept). Statistical analysis was performed comparing the samples to the moment condition of each drug. Representative result of three experiments (mean)

The data are expressed as the mean \pm SD

Table 1 shows that the masses of the anti-VEGF antibody recovered from each syringe did not differ significantly compared to the masses of the pre-assay syringe independent of the storage conditions of aflibercept $(p=0.32)$ and ziv-aflibercept $(p=0.50)$.

To evaluate if the different storage times and temperatures altered the binding affinity of these drugs to the VEGF molecule, an ELISA was performed to determine the concentration of anti-VEGF antibody able to bind to the recombinant human VEGF molecule.

For each drug, an expected concentration was estimated according to the initial concentration and subsequent dilutions, which was calculated as $0.200 \mu \mathrm{g} /$ $\mathrm{mL}$ for aflibercept and $0.125 \mu \mathrm{g} / \mathrm{mL}$ for ziv-aflibercept (Table 2). For aflibercept, the concentration of antiVEGF antibody detected in the pre-assay syringe $(0.208 \mu \mathrm{g} / \mathrm{mL})$ did not differ significantly from its expected concentration or when stored for 14 days at $4{ }^{\circ} \mathrm{C}(0.185 \mu \mathrm{g} / \mathrm{mL})$, at $-8{ }^{\circ} \mathrm{C}(0.196 \mu \mathrm{g} / \mathrm{mL}), 28$ days at $4{ }^{\circ} \mathrm{C}(0.175 \mu \mathrm{g} / \mathrm{mL})$, or at $-8{ }^{\circ} \mathrm{C}(0.147 \mu \mathrm{g} / \mathrm{mL})$ (Table 2). Similarly, for ziv-aflibercept, the pre-assay condition $(0.136 \mu \mathrm{g} / \mathrm{mL})$ also did not differ significantly either from the expected concentration or from the different storage conditions for 14 or 28 days, at $4{ }^{\circ} \mathrm{C}$ $\left(0.121\right.$ or $0.129 \mu \mathrm{g} / \mathrm{mL}$, respectively) or $-8{ }^{\circ} \mathrm{C}(0.130$ or $0.134 \mu \mathrm{g} / \mathrm{mL}$ ) (Table 2).

Table 2 shows that for both drugs regardless of the storage conditions, the concentrations of the antiVEGF antibody detected did not differ significantly compared to that in the pre-assay syringe, indicating that there was no difference in the anti-VEGF affinity to the VEGF molecule with aflibercept $(p=0.14)$ or zivaflibercept $(p=0.15)$.
Table 2 Evaluation of VEGF binding affinity in aflibercept and ziv-aflibercept samples under different storage conditions

\begin{tabular}{lll}
\hline & \multicolumn{2}{l}{ VEGF binding affinity $(\mu \mathrm{g} / \mathrm{mL})$} \\
\cline { 2 - 3 } & Aflibercept & Ziv-aflibercept \\
\hline Expected mass & 0.200 & 0.125 \\
Pre-assay & $0.208 \pm 0.041$ & $0.136 \pm 0.004$ \\
14 days $/ 4{ }^{\circ} \mathrm{C}$ & $0.185 \pm 0.036$ & $0.121 \pm 0.005$ \\
14 days $/-8{ }^{\circ} \mathrm{C}$ & $0.196 \pm 0.010$ & $0.130 \pm 0.006$ \\
28 days $/ 4{ }^{\circ} \mathrm{C}$ & $0.175 \pm 0.019$ & $0.129 \pm 0.013$ \\
28 days $/-8{ }^{\circ} \mathrm{C}$ & $0.147 \pm 0.014$ & $0.134 \pm 0.003$
\end{tabular}

Samples of aflibercept and ziv-aflibercept were added to ELISA plates, after coating the plates with anti-VEGF capture antibody and after binding the recombinant molecule of human VEGF (both R\&D components). The aflibercept's or ziv-aflibercept's anti-VEGF able to bind to the recombinant VEGF was detected by HRP-conjugated anti-human Ig and $\mathrm{H}_{2} \mathrm{O}_{2}$-OPD substrate, and quantification $(\mu \mathrm{g} / \mathrm{mL})$ was based on a standard curve performed with both drugs. The drugs were initially diluted in saline (1:200,000 for aflibercept; $1: 100,000$ for ziv-aflibercept). Statistical analysis was performed comparing the samples to the moment condition of each drug

The data are expressed as the mean \pm SD

The cultures of the syringe samples seeded in a blood agar plate under all conditions and storage time were negative.

\section{Discussion}

Anti-VEGF drugs are an important therapeutic arsenal that can be used to treat several eye diseases, mainly retinal disorders, most of which are chronic and degenerative. The therapeutic regimen requires several intravitreal applications of anti-VEGF drugs. The cost of the treatment is high for the patient and health system. Considering that these medicines can be injected nine to 11 times during year 1 of treatment (average, 17 times over 5 years), the related total costs and risks can be substantial $[14,16]$.

Compounding seems to be a possible way to reduce the cost, because the precise dose is administered, which reduces waste. However, administration of the compounded medication should maintain the safety and effectiveness of the treatment. In the current study, the in vitro effectiveness was assessed by analyzing the amount of recovered mass and binding capacity of the anti-VEGF drugs over time after compounding of the medications. The safety of compounding was assessed by checking the sterility of the compounded medications.

Several studies have reported the safety, sterility, and stability of different anti-VEGF drugs after compounding and storage $[7,10,20,30,33,35]$. Chen et al. [7] suggested that the content of the bevacizumab vials in multiple doses at $4{ }^{\circ} \mathrm{C}$ remains sterile and the antiVEGF activity is stable for up to 6 months. Nunes et al. 
confirmed the stability and sterility of bevacizumab for up to 30 days after compounding in polypropylene syringe at $-8{ }^{\circ} \mathrm{C}$ and $4{ }^{\circ} \mathrm{C}$ (Nunes [26], unpublished). Cao et al. [27] reported that compounding of ranibizumab and aflibercept in plastic syringes and storage for up to 4 weeks did not appear detrimental to the in vitro functional activity of these drugs. Mansour et al. [25] showed that ziv-aflibercept did not lose its anti-VEGF activity when stored at $4{ }^{\circ} \mathrm{C}$ in polycarbonate syringes for 4 weeks. Given this scenario, the compounding of antiVEGF has been adopted in several centers around the world.

The immunoenzymatic assay was carried out on the samples from each syringe to evaluate if the masses of aflibercept and ziv-aflibercept decreased. No significant loss of anti-VEGF mass was found when we compared the pre-assay syringe to the syringes stored for 14 and 28 days at the two different temperatures.

The second ELISA evaluated the binding affinity of both drugs to recombinant VEGF 14 and 28 days after compounding and after storage at different temperatures. No changes in the VEGF binding affinity was seen in these samples compared to the binding affinity of the pre-assay syringe, indicating that the in vitro ability of the anti-VEGF molecules to bind to their respective receptors was preserved.

The current study corroborates what is described in the literature, i.e., that compounded aflibercept and zivaflibercept do not lose their stability and binding affinity and are not contaminated if prepared under sterile conditions and stored at $4{ }^{\circ} \mathrm{C}$ or $-8{ }^{\circ} \mathrm{C}$ for 14 or 28 days.

A difference from most studies in which compounded aflibercept was evaluated was that in the current study the tests also were performed at $-8{ }^{\circ} \mathrm{C}$. Previous studies of drug storage and the manufacturer's instructions have suggested that the drugs be stored between 2 and $8{ }^{\circ} \mathrm{C}$ (refrigerator) and not frozen [7, 22, 27]. However, in the current study we found that for up to 28 days aflibercept and ziv-aflibercept stored at $-8{ }^{\circ} \mathrm{C}$ did not lose mass or have decreased binding affinity compared to the preassay condition, when both medications were maintained according to the manufacturer's instructions (at $4{ }^{\circ} \mathrm{C}$ ). These data suggested that compounded aflibercept and ziv-aflibercept can be stored for up to 28 days in polypropylene syringes at $4{ }^{\circ} \mathrm{C}$ and to $-8^{\circ} \mathrm{C}$.

The current protocols for treating age-related diseases determine the use of intravitreal injections monthly or almost monthly $[6,28]$. Although the incidence of injection-related endophthalmitis is relatively low, the possible consequences of the infection can be disastrous. Previous published reports have described cases of outbreaks of infections secondary to drug manipulation, not just for ophthalmologic use [20]. In 2011, the FDA issued an alert regarding cases of contamination that developed after use of intraocular bevacizumab at ophthalmology clinics in the US [17]. However, all patients were treated from the same drug batch compounded in the same pharmacy. Streptococcus mitis/oralis were the infectious agents present in most infected patients and all compounded syringes of the same batch that were unused [18].

The contamination of the syringes of the compounded drug in specific pharmacies was caused by breaks in the basic protocols of medication manipulation [19, 31], which emphasizes the importance of adopting strict protocols for the compounding process to avoid outbreaks or infections.

The current study showed that no syringes had microbial contamination in the microbiologic evaluations performed during all storage periods at both temperatures. The importance of assessing the stability and safety of these compounded drugs is essential to a possible costeffectiveness analysis when comparing the medications studied here with other commercially available medications. Demonstration of the in vitro stability of aflibercept and ziv-aflibercept after compounding and storage for up to 28 days should be followed by further studies to address the possible effects of in vivo functional activity.

\section{Authors' contributions}

$J L F, I M L M, D T, M E I, G M, L M J M$ and CBS conceived and planned the experiments. JLF, IMLM, DT, MEI, GM, LMJM carried out the experiments. JLF, IMLM, RS planned and carried out the experiments. GCA, JROD, CM contributed to sample preparation. JLF, RS, IMLM, DT, MEI, MEF contributed to the interpretation of the results. JLF and RS took the lead in writing the manuscript. MEF, JROD, GCA, IMLM, CM provided critical feedback and helped shape the research, analysis and manuscript. All authors read and approved the final manuscript.

\section{Author details}

1 Department of Ophthalmology, Santa Casa de Misericórdia of São Paulo, Rua Dr. Cesario Mota Junior 112, São Paulo, SP 01221-020, Brazil. ${ }^{2}$ Department of Microbiology, Immunology and Parasitology, Paulista School of Medicine, Federal University of São Paulo, São Paulo, SP, Brazil. ${ }^{3}$ Department of Microbiology, Santa Casa de Misericórdia of São Paulo, São Paulo, SP, Brazil. ${ }^{4}$ Vision Institute, Department of Ophthalmology, Federal University of São Paulo, São Paulo, SP, Brazil.

\section{Acknowledgements}

The authors thank Vision Institute, Department of Ophthalmology, Federal University of São Paulo, that sponsored this project. This manuscript has never been presented at a meeting.

\section{Competing interests}

The authors declare that they have no competing interests.

\section{Availability of data and materials}

All data generated or analysed during this study are included in this published article.

\section{Consent for publication}

Not applicable.

Ethics approval and consent to participate

Approval of the Ethics Committee of the Federal University of São Paulo: 8948020117. 


\section{Funding}

This study was funded by Vision Institute - IPEPO.

\section{Publisher's Note}

Springer Nature remains neutral with regard to jurisdictional claims in published maps and institutional affiliations.

Received: 10 July 2018 Accepted: 13 October 2018

Published online: 24 October 2018

\section{References}

1. Andrade GC, Dias JR, Maia A, Farah ME, Meyer CH, Rodrigues EB. Intravitreal injections of ziv-aflibercept for diabetic macular edema: a pilot study. Retina. 2016;36(9):1640-5. https://doi.org/10.1097/IAE.00000 00000001000 .

2. Andreoli CM, Miller JW. Anti-vascular endothelial growth factor therapy for ocular neovascular disease. Curr Opin Ophthalmol. 2007;18(6):5028. https://doi.org/10.1097/ICU.0b013e3282f0ca54.

3. Ashraf M, El Kayal H, Souka AA. Comparison between the short-term outcomes of bevacizumab and ziv-aflibercept in the treatment of primary diabetic macular oedema. Acta Ophthalmol. 2017;95(8):e803-4. https://doi.org/10.1111/aos.13352.

4. Ashraf M, Kayal HE, Souka AAR. Safety and efficacy of ziv-aflibercept in the treatment of refractory diabetic macular edema. Ophthalmic Surg Lasers Imaging Retina. 2017;48(5):399-405. https://doi. org/10.3928/23258160-20170428-06.

5. Ashraf M, Souka AA, El Kayal H, El Manhaly M, Abdallah MH. Threemonth outcomes of ziv-aflibercept in the treatment of diabetic macular oedema. Acta Ophthalmol. 2016;94(7):e669. https://doi. org/10.1111/aos.13111.

6. Brown DM, Kaiser PK, Michels M, Soubrane G, Heier JS, Kim RY, Sy JP, Schneider S, Anchor Study Group. Ranibizumab versus verteporfin for neovascular age-related macular degeneration. N Engl J Med. 2006;355(14):1432-44. https://doi.org/10.1056/nejmoa062655.

7. Chen YH, Wu PC, Shiea J, Lo LH, Wu YC, Kuo HK. Evaluation of the sterility, stability, and efficacy of bevacizumab stored in multiple-dose vials for 6 months. J Ocul Pharmacol Ther. 2009;25(1):65-9. https://doi. org/10.1089/jop.2008.0043.

8. Cheng YD, Yang H, Chen GQ, Zhang ZC. Molecularly targeted drugs for metastatic colorectal cancer. Drug Des Dev Ther. 2013;7:1315-22. https ://doi.org/10.2147/DDDT.S52485.

9. Chhablani J. Intravitreal ziv-aflibercept for recurrent macular edema secondary to central retinal venous occlusion. Indian J Ophthalmol. 2015;63(5):469-70. https://doi.org/10.4103/0301-4738.159909.

10. Das T, Volety S, Ahsan SM, Thakur AK, Sharma S, Padhi TR, Basu S, Rao Ch M. Safety, sterility and stability of direct-from-vial multiple dosing intravitreal injection of bevacizumab. Clin Exp Ophthalmol. 2015;43(5):466-73. https://doi.org/10.1111/ceo.12489.

11. de Oliveira Dias JR, Badaro E, Novais EA, Colicchio D, Chiarantin GM, Matioli MM, Verna C, Penha FM, Barros NM, Meyer CH, Farah ME, Rodrigues EB. Preclinical investigations of intravitreal ziv-aflibercept. Ophthalmic Surg Lasers Imaging Retina. 2014;45(6):577-84. https://doi. org/10.3928/23258160-20141118-15.

12. de Oliveira Dias JR, de Andrade GC, Kniggendorf VF, Novais EA, Maia A, Meyer C, Watanabe SE, Farah ME, Rodrigues EB. Clinical and electrophysiological evaluation after intravitreal ziv-aflibercept for exudative age-related macular degeneration. Retina. 2016;37(8):1499-507. https ://doi.org/10.1097/iae.0000000000001385.

13. de Oliveira Dias JR, de Andrade GC, Novais EA, Farah ME, Rodrigues EB. Fusion proteins for treatment of retinal diseases: aflibercept, zivaflibercept, and conbercept. Int J Retina Vitreous. 2016;2:3. https://doi. org/10.1186/s40942-016-0026-y.

14. Diabetic Retinopathy Clinical Research, Network, Wells JA, Glassman AR, Ayala AR, Jampol LM, Aiello LP, Antoszyk AN, Arnold-Bush B, Baker CW, Bressler NM, Browning DJ, Elman MJ, Ferris FL, Friedman SM, Melia M, Pieramici DJ, Sun JK, Beck RW. Aflibercept, bevacizumab, or ranibizumab for diabetic macular edema. N Engl J Med. 2015;372(13):1193203. https://doi.org/10.1056/nejmoa1414264.
15. Dib E, Maia M, Longo-Maugeri IM, Martins MC, Mussalem JS, Squaiella CC, Penha FM, Magalhaes O Jr, Rodrigues EB, Farah ME. Subretinal bevacizumab detection after intravitreous injection in rabbits. Invest Ophthalmol Vis Sci. 2008;49(3):1097-100. https://doi.org/10.1167/ iovs.07-1225

16. Elman MJ, Ayala A, Bressler NM, Browning D, Flaxel CJ, Glassman AR, Jampol LM, Stone TW, Network Diabetic Retinopathy Clinical Research. Intravitreal Ranibizumab for diabetic macular edema with prompt versus deferred laser treatment: 5-year randomized trial results. Ophthalmology. 2015;122(2):375-81. https://doi.org/10.1016/j.ophth a.2014.08.047.

17. FDA alerts health care professionals of infection risk from repackaged avastin intravitreal injections. http://www.fda.gov/Drugs/DrugSafety/ ucm270296.htm. Accessed 12 May 2017

18. Goldberg RA, Flynn HW Jr, Isom RF, Miller D, Gonzalez S. An outbreak of streptococcus endophthalmitis after intravitreal injection of bevacizumab. Am J Ophthalmol. 2012;153(2):204-208e1. https://doi. org/10.1016/j.ajo.2011.11.035.

19. Goldberg RA, Flynn HW Jr, Miller D, Gonzalez S, Isom RF. Streptococcus endophthalmitis outbreak after intravitreal injection of bevacizumab: one-year outcomes and investigative results. Ophthalmology. 2013;120(7):1448-53. https://doi.org/10.1016/j.ophtha.2012.12.009.

20. Gonzalez S, Rosenfeld PJ, Stewart MW, Brown J, Murphy SP. Avastin doesn't blind people, people blind people. Am J Ophthalmol. 2012;153(2):196-203e1. https://doi.org/10.1016/j.ajo.2011.11.023.

21. Holash J, Davis S, Papadopoulos N, Croll SD, Ho L, Russell M, Boland P, Leidich R, Hylton D, Burova E, loffe E, Huang T, Radziejewski C, Bailey K, Fandl JP, Daly T, Wiegand SJ, Yancopoulos GD, Rudge JS. VEGF-Trap: a VEGF blocker with potent antitumor effects. Proc Natl Acad Sci USA 2002;99(17):11393-8. https://doi.org/10.1073/pnas.172398299.

22. Khalili H, Sharma G, Froome A, Khaw PT, Brocchini S. Storage stability of bevacizumab in polycarbonate and polypropylene syringes. Eye (Lond). 2015;29(6):820-7. https://doi.org/10.1038/eye.2015.28.

23. Lai TYY. An update on intravitreal aflibercept in treating macular diseases. Asia Pac J Ophthalmol (Phila). 2017;6(3):225-7. https://doi. org/10.22608/APO.2017177.

24. Mansour AM, Al-Ghadban SI, Yunis MH, El-Sabban ME. Ziv-aflibercept in macular disease. Br J Ophthalmol. 2015:99(8):1055-9. https://doi. org/10.1136/bjophthalmol-2014-306319.

25. Mansour AM, Ashraf M, Dedhia CJ, Charbaji A, Souka AA, Chhablani J. Long-term safety and efficacy of ziv-aflibercept in retinal diseases. Br J Ophthalmol. 2017;101(10):1374-6. https://doi.org/10.1136/bjophthalm ol-2016-309724.

26. Nunes RP. Estudo de Custo-efetividade dos tratamentos farmacológicos para a degeneração macular relacionada a idade. Thesis presented to Federal University of São Paulo for the title of PhD. São Paulo, 2015.

27. Paul M, Vieillard V, Roumi E, Cauvin A, Despiau MC, Laurent M, Astier A. Long-term stability of bevacizumab repackaged in $1 \mathrm{~mL}$ polypropylene syringes for intravitreal administration. Ann Pharm Fr. 2012;70(3):13954. https://doi.org/10.1016/j.pharma.2012.03.006

28. Rosenfeld PJ, Brown DM, Heier JS, Boyer DS, Kaiser PK, Chung CY, Kim RY, Marina Study Group. Ranibizumab for neovascular age-related macular degeneration. N Engl J Med. 2006;355(14):1419-31. https:// doi.org/10.1056/nejmoa054481.

29. Sharma T, Dhingra R, Singh S, Sharma S, Tomar P, Malhotra M, Bhardwaj TR. Aflibercept: a novel VEGF targeted agent to explore the future perspectives of anti-angiogenic therapy for the treatment of multiple tumors. Mini Rev Med Chem. 2013;13(4):530-40.

30. Shehab N, Brown MN, Kallen AJ, Perz JF. U.S. compounding pharmacyrelated outbreaks, 2001-2013: public health and patient safety lessons learned. J Patient Saf. 2015;14(3):164-73. https://doi.org/10.1097/ pts.0000000000000188.

31. Sheyman AT, Cohen BZ, Friedman AH, Ackert JM. An outbreak of fungal endophthalmitis after intravitreal injection of compounded combined bevacizumab and triamcinolone. JAMA Ophthalmol. 2013;131(7):8649. https://doi.org/10.1001/jamaophthalmol.2013.88.

32. Sugimoto MAA, Toledo VPCP, Cunha MRR, Carregal VM, Jorge R, Leao $P$, Fialho SL, Silva-Cunha A. Quality of bevacizumab (Avastin $(R)$ ) repacked in single-use glass vials for intravitreal administration. Arq Bras Oftalmol. 2017;80(2):108-13. https://doi.org/10.5935/0004-2749.20170026. 
33. VanderBeek BL, Bonaffini SG, Ma L. Association of compounded bevacizumab with postinjection endophthalmitis. JAMA Ophthalmol. 2015;133(10):1159-64. https://doi.org/10.1001/jamaophtha Imol.2015.2556.

34. Videkar C, Kapoor A, Chhablani J, Narayanan R. Ziv-aflibercept: a novel option for the treatment of polypoidal choroidal vasculopathy. BMJ Case Rep. 2015. https://doi.org/10.1136/bcr-2015-212988.
35. Yannuzzi NA, Klufas MA, Quach L, Beatty LM, Kaminsky SM, Crystal RG, D'Amico DJ, Kiss S. Evaluation of compounded bevacizumab prepared for intravitreal injection. JAMA Ophthalmol. 2015;133(1):32-9. https://doi. org/10.1001/jamaophthalmol.2014.3591.
Ready to submit your research? Choose BMC and benefit from:

- fast, convenient online submission

- thorough peer review by experienced researchers in your field

- rapid publication on acceptance

- support for research data, including large and complex data types

- gold Open Access which fosters wider collaboration and increased citations

- maximum visibility for your research: over 100M website views per year

At BMC, research is always in progress.

Learn more biomedcentral.com/submissions 